\title{
Catholic Church Towards Sovietization of Culture and Polish Society in Communication of the Polish Embassy at the Vatican in the Years 1956-1968
}

\author{
MAREK BODZIANY* - TOMASZ LANDMANN** \\ Katolická církev proti sovietizaci kultury a polské společnosti v komunikaci \\ polského velvyslanectví ve Vatikánu v letech 1956-1968
}

\begin{abstract}
The article aims to present the culture-forming role of the Catholic Church, which emerges from selected communications of the Polish Embassy at the Vatican, in opposition to the sovietisation of Polish culture developed by the communist authorities of the People's Republic of Poland in the years 1956-1968. Materials from the Archive of the Józef Piłsudski Institute in America and available literature constituted the basis for the analysis. The undertaken research considering the sources fills a significant gap in the knowledge about the Catholic Church's opposition to the process of sovietisation of Polish culture during the Cold War. It should be emphasised that in the post-war period the Church was the institution that shaped Christian values and a kind of "bastion" of resistance to the authorities whose one of the goals was to sovietise Polish culture. It continued the discourse on the ground of the expression of the inability to reconcile the communist ideology with Christian values in European, including Polish, culture. It also acted as a correspondent for the affairs of oppressed nations subjected to the course of sovietisation. The undertaken research is an answer for lack of knowledge on the Catholic Church opposition towards the process of sovietising Polish culture during the Cold War. All the above allows the hypothesis that the Catholic Church during this period was the only one successful opposition to the PRL authorities which were against the Polish culture and society.
\end{abstract}

Keywords: Polish embassy at the Vatican; cultural security; communism; the Church

DOI: $10.14712 / 23363525.2020 .18$

\section{Introduction}

The role of the Catholic Church in the society dominated by the influence of the communist authorities in Poland in 1945-1989 deserves special recognition in the era of easier access for historians to archival sources and objective historical accounts. Communists strengthening their power in the 1950s in the People's Republic of Poland treated the Catholic Church as the "main ideological enemy" [Jedraszewski 2008: 312], proposing a model of socio-cultural life and cultural security different from that in 1918-1939. It must have led to numerous manifestations of resistance from the Polish society, in which the influence of the Church was considerable, especially in the sphere of strengthening elements of national culture based on Christian values [Miernik, 2003: 31].

\footnotetext{
* Prof. Marek Bodziany, deputy dean of Security Studies in General Kościuszko Military University of Land Forces in Wroclaw - Faculty of Security Sciences. E-mail: m.bodziany@interia.pl

** Dr. Tomasz Landmann, doctor of humanities in the discipline of history. General Kościuszko Military University of Land Forces in Wroclaw. E-mail: t.landmann@wp.pl
} 
The research was based on two connected periods of sovietisation of culture and the Polish language - the years of 1956-1961 and 1962-1968. Awareness of the extent of the subject matter means that the issues of the PRL authorities' policy towards the Church, known from the publications by Henryk Dominiczak [2000], Antoni Dudek, Ryszard Gryz [2006], Jerzy Eisler [2004: 385-402], Piotr Stanisz [2000: 259-270] and Jan Żaryn [2003; 2005: 11-34; 2010: 35-122], have been omitted. The focal point of the discussion is the content of the information elaborations of the Polish Embassy at the Vatican, created based on various sources from the country and abroad, such as contacts with the Polish government in exile, national and foreign press, analysis of legal acts issued by the PRL authorities, contacts with representatives of the Holy See or the hierarchs of the Catholic Church in Poland. The communications of the Embassy of the Republic of Poland to the Vatican enables conclusions to be drawn on the critical role of the Church in Polish society during the intensification of cultural sovietisation in 1956-1961. The issue has not been sufficiently elaborated, even considering Jan Żaryn's general study of the archive records [Żaryn 1998]. The historiography is dominated by the view on the Polish Embassy at the Vatican during World War II, and the considerations of most authors about the post-war functioning of the institution - as Dominika Wronikowska emphasises - focused on the process of resuming diplomatic relations between the PRL and the Holy See [Wronikowska 2016: 38,40$]$.

The second period of the research is connected to the change of the PRL authorities' Polish politics towards culture and church. The beginning of the 1960s brought a new approach from the communist authorities of the People's Republic of Poland to the implementation of the previously imposed direction of sovietisation of the Polish society and culture. The change was evolutionary and it targeted the intensification of communist authorities' actions towards those social groups that could constitute - in the opinion of decision-makers - the reactionary environment that was hostile to the communist regime and fuelled the Polish society's opposition towards the imposed power. The Catholic Church, having a broad impact on the society and carrying out culture-creating functions at the same time, was one of such environments [Bodziany 2019: 259-260]. From the beginning of the 1960s, the legislator's efforts were aimed at marginalising the role of the Church by, inter alia, removing religious education from schools in 1961 [DEUS 1961] or adopting a regulation imposing complex accounting and tax duties on churchpersons and religious congregations in 1962 [KCR 1962; Krawczyk 2017: 148; Dudek 1995: 158] ${ }^{1}$. In the same year, constituting the beginning of the adopted time caesura, the process of liquidation of Catholic religious schools and care centres [Kolasa 2010: 383-410] ${ }^{2}$ was completed, and the idea of liquidation of lower spiritual seminaries was implemented [Mazglewski 2007: 31-57]. The ideologically strengthened policy of the authorities inscribed in the direction of the sovietisation of the Polish culture and society had to face the Polish Church's

1 It is emphasised in the literature that these duties, together with the more stringent tax laws imposed on Church circles already in 1959, were intended to create concerns among the clergy as to the possible nationalisation of church property, preceded by attempts to register it thoroughly by the Office for Religious Affairs along with its local agencies. Meanwhile, the communist authorities sought to create a tight tax system, especially for the need to execute the tax arrears of the Church, thereby treating the tax policy as an effective means to compromise the mission of the institution widely influencing the Polish society in the early 1960 s.

2 For more on this issue, with the emphasis on the situation in the city of Łódź. 
response [Krajczyński, 2017: 62] $]^{3}$ supported by the Holy See. Various manifestations of the above can be found in the documents gathered at the Polish Embassy at the Vatican.

\section{The Catholic Church's Approach to Manifestation of Sovietisation in 1956-1961}

The situation in Poland at the turn of 1955 and 1956 proved that the Catholic Church tried to strengthen its weakened position under the conditions of repression from the communist authorities. Subsequent communications of the Polish Embassy at the Vatican prove that the Holy See with the Pope at the head was an essential source of support for the Church's efforts. At the end of 1955, in a letter to the faithful in Poland, Pope Pius XII expressed support for the cause of the Catholics objecting to the communist regime, which resulted in "closing the ranks of fighting Catholicism and strengthening the position of the Church" [CEROV 32, 1956]. In 1956, there was also opposition to the violation of Polish workers' rights, mainly in the context of events of the Poznan June and the arguments for the failure of communism in the organisation of a just social system, also on the example of Poland [CEROV 35, 1956].

In the aspect of the cultural security of Poland, which emerged before World War II as part of its independent rule and state sovereignty, including the participation of Christian values, after 1945 the authorities undermined the previously achieved heritage. Attacking the Church and attempts to marginalise its contribution to the development of culture and social life was in no small extent an element of the communist state in 1956-1961 [Bodziany 2019: 259]. The literature emphasises that the Catholic Church "was attacked not only as a religious institution but also as the last obstacle to the implementation of a totalitarian model programmed by the communist authorities, which would ensure its full control over the society" [Zabłocki 1999: 120]. The communications conveyed by the Polish Embassy at the Vatican indicated that the Church did not intend to accept the oppression imposed by the communists passively. In October 1956, it was announced that "The Holy See and the Catholic hierarchy in Italy vividly reacted to the anti-Soviet movement in Central and Eastern Europe" [CEROV 51, 1956], which was mainly motivated by social movements in Poland and Hungary. The Embassy of the Republic of Poland at the Vatican noted that there were demonstrations on the streets of Rome called around the slogan of solidarising with the participants of anti-communist rallies in both Central European countries [CEROV 51, 1956].

The collected archives show that the Church took an unambiguous stance in the aspect of the Catholic social and economic program in the countries of the communist bloc. The document of April 18, 1956, emphasised the view of Pope Pius XII, according to whom the Universal Church would not cease in resistance to attempts made in individual communist countries after World War II in connection with the state's excessive interference in the private sphere to destroy it or seriously violate to the detriment of the freedom of human work and entrepreneurial activity. In turn, as for the social program, the Church expressed its opposition to the communist state's monopoly on the education of youth. That was

\footnotetext{
The answer resulted not only from the threat to important Christian values in the Polish culture but also the imposition of number of restrictions destabilising the activity of the Church, the internal structure of the institution, as well as aiming at "destabilising and destroying the Church".
} 
particularly important in the era of the educational model that the communist state offered to the citizens of Poland. The Pope also referred to the harmful consequences of central planning in the social sphere of religious freedom violation. He showed the connection of the communist regime with the destruction of the spiritual heritage in Catholic countries after the Second World War [CEROV 22, 1956]. This heritage should be assessed as an essential element of the development of Polish culture over the last centuries.

An important element of strengthening cultural security in every country is the preservation of the culture and acquis shaped during the long-lasting process of stabilising social relations by law. In the opinion of the Holy See, the mid-1950s changes in the communist countries, including Poland, aimed at ruining the results of this process. On April 29, 1956, the article entitled "Confessioni e prove" published in the daily newspaper of Vatican City State "L'Osservatore Romano" analysed the new direction in the development of criminal law under the influence of communism in countries dependent on the Soviet Union. The authors of the article concluded that 'objective justice' and 'the Soviet natural law' are in full and intentional contrast with the tradition of justice of free people" [CEROV 23, 1956]. The codified system of criminal law in such countries as Poland, Czechoslovakia or Hungary was built on subordinating the meaning of crime and punishment solely to the interest of the communist state, not implementing the principle of social justice [Ibid.]. It should be recognised that the mission of the state fulfilled in this way was a threat to the principle of a fair justice system in communist Poland in 1956-1961. The Pope representing the Catholic Church opposed such a direction of the development of criminal law as an essential element of the legal culture, and at the same time, the cultural security of the then states.

When it comes to the sovietisation of the Polish culture, the communications of the Polish Embassy at the Vatican paid attention to the danger of progressivism, which is poorly known in historiography. In the Holy See's view: "Progressivism consists in combining false progress with the truncated Catholic faith" [CEROV 39, 1956]; however, in essence, it concerned the Communists' attempts to forbid progressive changes within the Church itself and its doctrine, which would serve to weaken the unity of believers and popularise the leftist program within Catholic social teaching. The Pope obliged the bishops to warn the faithful in Poland as well as in other communist countries against progressivism, threatening with a formal exclusion of people supporting the analysed socio-religious movement from the Church structures [Ibid.].

In November 1956, another communication addressed the question of eliminating the importance of the Church and religion from the Eastern Borderlands in the context of the situation in the eastern part of the Vilnius archdiocese subordinated to the Soviet Union. It objected to the administration direction pursued by Moscow, which included closing churches, hindering clergy's ability to influence society, as well as spreading atheist propaganda in the local press and schools. At the same time, it was shown that despite the intensified actions of the communists, the Catholic population remained faithful to the traditions and cultural values stemming from Christianity. The Catholic Church in Poland could count on the support of the Vatican in the context of confirming the Vatican's demand for the abolition of the Decree adopted on February 9, 1953, on filling clerical positions [CEROV 52, 1956].

The document describing the results of the Primate of Poland Stefan Wyszyński's visit to Rome in May and June 1957 presents interesting conclusions. The communist power 
in Poland, realising the authority of the Primate, tried to present the official visit to Rome as an anti-regime mission of political rather than primarily religious nature. Press propaganda was used to discredit it and inspire messages in the leftist foreign press. The document contains references to the attempts made by the communists to divide the Church in Poland and separate Catholics from extensive contacts with the Holy See. Among the expected declarations, as the result of S. Wyszyński's visit, it was stated that: "The Vatican will certainly do its utmost to organisationally and personally renew the Polish Church and strengthen it all the more so that it may only be a favourable economic situation, a pause in persecution" [IPPR 8. 5. 1957; Szafrański 2005: 378; CEROV 45, 1956] ${ }^{4}$. The Primate started talks with Pope Pius XII on the possible creation of new dioceses in Łowicz, Kalisz, Radom and Bydgoszcz, although the need to change the Concordat of 1925 and discuss the matter with the anti-democratic regime in Poland was noticed [OFCP 1957; Marecki, Musiał 2007: 13; Żaryn 2004: 99] $]^{5}$. The Pope gave assurance to S. Wyszyński of maintaining the activities of the Polish Embassy at the Vatican (despite the communist authorities' expectations as to its liquidation) [Grajewski 2013: 216] ${ }^{6}$, as well as priest Józef Gawlina's mission [Dzwonkowski 2012: 56]7.

Another subject of discussion during the Primate's visit was to fill posts in the Cracow, Poznań and Vilnius metropolitan areas, which did not require changes to the Concordat's content, but related to the need to obtain the consent of the communist authorities. The problem of Polish bishops' subsequent visits to Rome, which were impossible for political reasons in the then conditions in mid-1957, was discussed. Primate Stefan Wyszyński also

4 The document mentions the thaw of October 1956 in the persecution of the Church, which also resulted in the partial liberalisation of the communist authorities' policy towards various social environments. The thaw particularly resulted in the release of S. Wyszynski from his internal exile, the reintroduction of religious education in schools, the rehabilitation of some clerks falsely accused of anti-system activities, or the return of nuns to facilities previously confiscated by the state. The assessment preserved in the documents of the Embassy of the Republic of Poland at the Vatican shows that the hierarchs of the Catholic Church in Poland regarded the thaw of October 1956 only as a temporary state, a pause in the further persecution of the Catholics by the communists.

5 The necessity in question was the consequence of the adoption on December 31, 1956, of decree regulation on the organisation and occupation of church positions in Poland. The Decree laid down that creation, transformation, abolition, as well as the establishment of territorial boundaries and headquarters of dioceses and Catholic parishes required the prior consent of the state on the ground of an agreement with the competent PRL authority. It is emphasised that under the Decree of December 31, 1956, on the organisation and occupation of church positions (Journal of Laws of 1957, No. 1, item 6 [OFCP, 1957]) the state withdrew from the direct shaping of personnel policy within the Catholic Church, but it left itself the possibility of far-reaching interference in this field. The view of the legislative efforts of the communist state to limit the freedom of the religious movement in Poland, and thereby weakening the role of the Church in influencing society, can be found in historiography.

6 The issue of the liquidation of the Polish Embassy at the Vatican as a government-in-exile cell returned in subsequent conversations between representatives of the communist authorities and Polish Church hierarchs. Not only did the former postulate the normalisation of relations between the authorities and Church in the PRL but also the liquidation of the so-called residual dioceses in Drohiczyn, Białystok, and Lubaczów in 1944-1989.

7 After World War II Józef Gawlina took over the role of the Spiritual Guardian of the Poles in exile, acting as the so-called Protector of Polish Emigration. He was responsible for inspiring members of the Polish emigration in stimulating religious zeal, and organising clerical seminaries abroad; he also conducted activities related to publishing and the establishment of Polish Catholic Missions. In his pastoral work, he fulfilled the task of the Ordinary Bishop of the Polish in Germany, the providential shepherd, and a kind of spiritual guide of the Polish emigration all over the world. The then communist authorities of the People's Republic of Poland assessed his activity as uncomfortable for them. 
received an explicit declaration that: "The Holy See does not want and cannot enter the path of understanding and co-existence with communism" [IPPR, 8. 5. 1957]. The role of the Catholic Church in the situation shaped in Poland after the Second World War in connection with the imposition of communist rule was assessed as follows: "It requires, on the one hand, saving what can be saved by the Church and, on the other hand, excludes any imitation in other countries. (...) The victory of the Polish Catholics, the release of the Primate, and the bishops, and the visit to Rome are first and foremost the result of the resistance of the Catholic mass in Poland, the consequence of the resolute 'no' which the Poles told communism and Moscow" [Ziętara 2001: 26; Gałaszewska-Chilczuk 2006: 55] ${ }^{8}$.

The Church's support for the Polish Catholics on the part of the Holy See was also oriented around inspiring the publication of information messages in the Vatican and Italian press. The account of the private audience attended by Ambassador Kazimierz Papée with Pope John XXIII on January 11, 1960, proves that information on the persecution of the Polish Catholics appeared, for example, in the Italian weekly "Vita". They concerned the restrictions imposed by the communist authorities of the PRL on the freedom of disposing of Church property, the Church's taxation in Poland, the prevention of religious education in public schools, the practice of appointing clerics for military service or imposing on the Church formal difficulties in erecting new temples. The article published in the weekly "Vita" also discussed the role of the Catholic University of Lublin in educating cadres in the spirit of the values of Christian culture, and at the same time the actions of communist authorities aimed at weakening the importance of universities in the Polish society ${ }^{9}$ (especially by abolishing the three main fields of education and contributing to reducing the number of listeners by half, up to 1800 people). The message referred to the show trial of Bishop Czesław Kaczmarek (it took place in 1953), wrongly accused of spying for the Vatican and the United States, collaborating with the Germans, and acting to the detriment of the socialist system of the PRL [CEROV 1, 1960]. Not only did the usefulness of such a press release serve to increase awareness among the Italian society of the actual oppression of the Church by the communists in Poland but also the Holy See's support for the cause of the Polish Catholics living during the persecution of the Church in the PRL.

The information published in the Vatican newspaper "L'Osservatore Romano" proved to be difficult to overestimate, primarily due to the authorisation of the spokesperson of the Secretariat of the State of the Holy See to publish official positions and doctrinal views of the Church on social matters. The Polish Embassy at the Vatican attributed the critical role to Professor F. Alessandrini, the author of several publications consistent with the doctrine of the Church and condemning communism as an ideology incompatible with the values of the Christian culture. The activity became increasingly important due to the communist efforts to inspire the press in Italy and other Western European countries for a false message referring to the rapprochement of the Soviet Union and the Vatican to regulate

8 Furthermore, the document underlines the role of the Polish western emigration as "a factor strengthening resistance of the society in the country and supporting this resistance towards the West" [Ibid.]. The literature on the subject provides information that the situation and persecution of the Catholics in Poland "aroused deep concern for emigration", while Polish emigre circles closely watched events in Poland, not only at the demands of the release of Primate Wyszyński during internment in 1953-1956 but also in a later period.

9 The scale of these activities is best evidenced by the fact that in the early 1960s the communist authorities developed an organised apparatus for controlling the activities of lecturers teaching at the Catholic University of Lublin. It consisted of 32 information sources, 15 of which were priests obedient to the communists. 
reciprocal relations based on consent and mutual tolerance. "L'Osservatore Romano" officially constructed a sincere message about the attitude of the Church to Bolshevism, the persecution of the Church in Poland and other satellite countries of the Soviet Union [CEROV 5, 1958].

On March 7, 1960, the Polish Embassy at the Vatican noted that the intensified action against the Catholic Church in Poland did not evoke "any more vivid reaction" [CEROV $7,1960]$ in the international environment, except for the Vatican which was favourable to Poland. The acts of discrimination against the Church and the Catholics in Poland were listed, and the reference was made to the case of Bishop Kaczmarek [CEROV 6, 1960; Chmielowiec, Lasota and other 2003: 12 $]^{10}$, removal of secular catechists opposing the communist ideology in the PRL, increased control over the activities of seminaries in order to limit the Vatican's influence on the development of religious education in Poland, and the systematic formulation of threats against influential Church hierarchs to weaken their ties to the faithful $\left[\right.$ CEROV 6, 1960] ${ }^{11}$.

In 1961, the communist authorities in Poland imposed new regulations on the society resulting in the cessation of religious education in schools, forcing priests to teach religion at parishes, with strict control of educational authorities [DEUS 1961; Mezglewski 2000: 28 ${ }^{12}$. The issue was also discussed in the communiqués of the Polish Embassy at the Vatican. For instance, in the communication of September 14, 1961, the support was expressed for citizens who opposed the new education regulation in the PRL. It was noticed that the authorities not only formally deprived people of the possibility of teaching religion in public schools but also introduced regulations resulting in hindering the teaching of the subject outside of schools. The fragments of press releases in the "LO'Osservatore Romano" were quoted as undermining the claims of the communist authorities in Poland to "rationing' teaching religion even in churches and church buildings. In this way, they violate the Church's most fundamental rights and push themselves into the area where their presence is an unacceptable rape" [CEROV 28, 1961]. The communication confirmed the violation of the principle of the independence of state authority from the Church on the example of the forced meeting of parish priests convened by local offices for

10 The case of Czesław Kaczmarek, the Kielce Bishop, was of interest to the Polish Embassy at the Vatican that constantly monitored the authorities' actions in relation to the priest after his release from prison, and publicised persecution in other communications, seeking a representative example of direct influence of the repressive communist system on the clergy and the Church in Poland. The message of February 27, 1960, informed about the compulsory departure of the Bishop to Krynica, probably faked to remove him from the diocese and deprive him of the function of the Ordinary. The case of Bishop Kaczmarek received the support of the Episcopate and Pope John XXIII who expressed his support for the clergyman in a personal letter, refusing to recognise the postulate of communist authorities of Poland to dismiss the priest from his position under the canon law.

11 The communists' activities in Poland in the early 1960s noted by the Polish Embassy at the Vatican were assessed as stages "on the way to separating Poland from the Universal Church, transforming the clergy into a regime's tool, and finally to complete de-Christianisation of Poland".

12 As noted in the literature, the specific provision of the Act did not include the sources of prohibition on teaching religion in public schools but the supplementary ordnance and instructions of the Minister of Education on the conduct of catechetical classrooms with lessons for those children whose parents or guardians expressed such a need addressed the issue. In practice, the regulations provided for numerous formal restrictions on the establishment of catechetical classrooms at parishes. It should have been perceived as the manifestation of discrimination and the form of increasing persecution of the Catholics in the early 1960s in the People's Republic of Poland. 
Church affairs on August 21, 1961, to make them listen to the government's law and sign terms of administering catechetical classrooms at parishes. The actions of the authorities were assessed in the Church environment as "a brutal intervention (...) into the internal jurisdiction of the Church, an intervention made with deliberate omission of hierarchy" [CEROV 28, 1961].

The Polish reform of the education system, which, in the opinion of the Polish Embassy at the Vatican, had been prepared since the turn of the 1950s and 1960s, was recognised by the journalist community associated with the papal newspaper "L'Osservatore Romano" as an example of harassing the Catholics behind the Iron Curtain, and as exemplification of the political-ideological and cultural increase of the influence of communist authorities on shaping the youth in the spirit of socialist values. The latter posed a threat to the cultural identity of the Poles who mostly identified with Christian values [CEROV 4, 1961].

Another cultural threat identified in the assessment of the circles associated with the Catholic Church in the years under analysis concerns the uncertain position of a significant number of European intellectuals referring to communism. In the article published in February 1961 in the weekly "L'Osservatoredella Domenica", Professor F. Alessandrini showed the weakness of Western intellectual movements, which were unable to see the true nature of communism as a reactionary social doctrine threatening democracy, private property, or religious and ideological freedom in the countries of the 1950s and 1960s [CEROV 6, 1961]. Recognising the auxiliary importance of emigration circles and the Church's search for international help, these arguments can be considered as fundamental in discussing the real scale of threats of communism in the message formulated by the Polish Embassy at the Vatican.

The years 1956-1961 characterised by intensified persecution of the Catholic Church in Poland did not lead to breaking the institution that had a significant impact both on the process of integration of the Polish society and strengthening the cultural values and norms shared in it [CEROV 7, 1961; Pawlina, 2002: 24] ${ }^{13}$. In his two speeches of March 19, 1961, commented by the Embassy of the Republic of Poland at the Vatican, Primate Wyszyński assured compatriots of the independence of the hierarchy, as well as appealed to them to strengthen attitudes of defending Christian values in the fight against persecution carried out by the communists. S. Wyszyński discredited the PRL central authorities' claims against the Vatican about inciting the Poles to fight against communism allegedly at the expense of reducing the protection of the Church's position in the country. He mentioned the role of Vatican Radio in unmasking the lies cultivated by the camp of W. Gomulka in their attempt to split between the Catholics in Poland and the bishops maintaining close contacts with the Holy See. He underlined the lack of freedom of conscience guaranteed by the law in the People's Republic of Poland as an immanent element of culture in the Christian society, as well as many other aspects of criticism of the actions of state authorities in the face of the communist camp's strivings aimed at marginalising the role

13 The Polish Embassy notes the best evidence at the Vatican on April 13, 1961 - an increase in the number of priestly vocations in the PRL compared to the situation immediately after the end of World War II, despite the intensification of persecution by the communist authorities. The data is confirmed in the literature, because in fact the dynamics of admission to diocesan seminars was the highest in 1950-1954 (almost 1000 vocations per year), and slightly lower in 1955-1960 (almost 800 per year), thus significantly exceeding the number of vocations in the years 1945-1950 (563 per year). 
of the Catholic Church in the Polish society and influencing the formation of national culture [Szymanowski 2009: 51, 163; CEROV 9, 1961] ${ }^{14}$. Cardinal Wyszyński's speeches were crucial for inspiring the official Vatican journal. Therefore, on March 24, 1961, Professor F. Alessandrini's article entitled "La Chiesa in Polonia" enumerated specific manifestations of the persecution of the Catholics in Poland and gave support to the Polish Church in the fight against the imposed direction of the sovietisation of culture $[C E R O V \text { 10, 1961 }]^{15}$. Consequently, it should be stated that the position of the Vatican and the Church in Poland in the time perspective under the study remained uncompromising about the inability to reconcile the Christian values with the cultural model proposed by the communists, inscribed in the direction of the sovietisation of culture.

\section{The Catholic Church's Approach to Manifestations of Sovietisation in the Period 1962-1968}

Facing the strategy of persecution implemented by the communist authorities against the Catholic Church in Poland at the turn of the 1950s and 1960s, the Church sought to maintain communication with the Holy See. At the beginning of January 1962, the Polish Embassy at the Vatican City recalled an article published in "L'Osservatore Romano" in December of the preceding year, which had been supposed not only to raise the awareness of the Italian society of the fight of Polish Catholics for their rights, but also to express support for the Church in Poland. The article contained a message formulated by Pope John XXIII, which was read out in all Polish churches during Christmas 1961 [Żaryn 1998: 35; CEROV 1, 1962 $]^{16}$. In the author's commentary on the Pope's message, the author of the

14 In the opinion of the Hierarch, there were various government institutions in Poland in the early 1960s whose specialisation included secularisation of the society and the eradication of the Christian values from the national culture, primarily by influencing young people. In the criticism of the cultural policy of the PRL, there was also a reference to the condemnation of atheist contents on the example of one of the anti-Church films shown in the cinemas (although the title was not mentioned, the available historical knowledge indicates that it might have been the film "Mother Joanna from Angels" by Kawalerowicz). As a summary, S. Wyszyński stated: "The Catholic Church is indeed opposed to all oppression, and we will not defend ourselves if someone opposes to us with this objection."

15 The listed manifestations of the discrimination of the Church included fiscal oppression of Church institutions, abolition of teaching religion in public schools, promotion of religious organisations such as the PAX Association and the Polish-Catholic Church in the Republic of Poland cooperating with the regime, or favouring building sectarian temples while limiting the possibility of erecting Catholic temples in newly emerging urban settlements (the example of Nowa Huta). Other manifestations of persecution, which the society with the support of the Church protested, concerned the closure of smaller clerical seminaries and novices, revisions in libraries of Catholic institutions, confiscation of theological textbooks, practising anti-religious propaganda in cultural messages, as well as a systematic formulation of threats of closing female religious congregations. It should be assumed that drawing attention by the Church to the mentioned above manifestations of the activities of public authorities of the People's Republic of Poland constituted an essential element of protecting the cultural heritage of Poland, permanently inscribed in the context of the Christian values.

16 According to a correspondent from the Polish Embassy at the Vatican, the papal message was "for the world about the position of the Church fighting in Poland. It attested that the Church in Poland in her struggle is not left alone by the Universal Church, and that the whole Church, with the Pope at the forefront, is united and joint with the Church in Poland". As Jan Żaryn noted, in this case, the Holy See continued the strategy of providing support to the Church in Poland, intensified particularly after the events accompanying the arrest and the prison of Stefan Wyszyński in the years 1953-1956. The reports of the Polish Ambassador to the Vatican also from the early 1960s stressed the convergence between the Polish raison d'etat, i.e. the interests of the Polish Government in exile and the decisions of the Vatican diplomacy, were stressed. 
article, Professor F. Alessandrini, referred to the Marxist-Leninist tactics implemented by communists in Poland, whose aim was to combat the Catholic faith in the Polish society. He presented an example of the authorities' intrusion in November 1961 to one of the churches in Poznań, where young people gathered, and the arrest of several participants. The event triggered opposition from Archbishop of Poznań and Primate Stefan Wyszyński. The Primate urged the authorities to establish a parliamentary committee for examining the regime activities that were, in the opinion of the Church, inconsistent with the Constitution of the PRL and the natural rights of every human being. Primate Wyszyński supported the demand with six manifestations of the unlawful participation of the authorities in exerting pressure on the Church and the Polish society. This concerned the creation of political guidelines in relation to teaching religion, limiting the rights of nurses, formulating unfair tax laws for the clergy, foreclosing access to higher education for priests and religious, prohibitions and restrictions on the development of Catholic associations, as well as the lack of recognition of existing church institutions as legal persons [CEROV 1, 1962]. All the arguments were part of the rhetoric explaining how the authorities tried to foist a postulated model for the sovietisation of culture and social relations upon the society in the early 1960s, during the PRL period.

An interesting manifestation of the PRL authorities' activities targeted at the sovietisation of the culture and society were attempts to marginalise the issue of the Katyn Massacre, which was recalled due to the demands of some Polish People's Army soldiers at the turn of 1961 and 1962. One report of the Polish Embassy at the Vatican noted that the launch of a court procedure for committing the Katyn Massacres was demanded at that time. However, the above deeds received the immediate authorities' reaction consisting in disciplinary and criminal proceedings against some members of the officer corps of the Army. In the result, some officers were released, some others were degraded, while the most active were expelled from the Army [CEROV 4, 1962]. The example testified to the communist authorities' involvement in concealing the actual nature of the Katyn Massacre and preventing its adverse publicity to counteract the revealing of actual significance of it. It also fell within the scope of the classical actions consisting in social disinformation and depriving citizens of access to reliable information [Habielski, 2009: 97] 17. The event should be considered as the denial of historical truth, which constituted an exemplary threat to the cultural security of the Polish nation.

On the eve of the Second Vatican Council approaching in October 1962, Pope John XXIII uttered words expressing "strong stigmatisation of persecution of the Church behind the Iron Curtain" [CEROV 10, 1962]. Among the more specific ways of communists' (including Polish ones) activity towards societies and their attempts to eradicate Christian values from national cultures, the highest Catholic Church authority distinguished: using the strategy of extreme materialism, negating the religious order as a way of organising the community, denying the usefulness of the Church as a social institution, proclaiming the idea of progress only as an effect of the development of the temporal state

17 It is emphasised in the literature that similar practices, which had been intensively undertaken already in the 1950s and were conducive to state propaganda towards historical events, constituted an element of shaping social attitudes and beliefs about the past as well as the Polish nation's historical memory. Thus, they influenced the cultural life in the period of the People's Republic of Poland, but they distorted the actual history of Poland and its culture since they based on disinformation of the society. 
of possession, as well as the actual enslavement of society through the use of deception and strength [Ibid.]. Another communiqué of the Polish Embassy addressed a message of Pope John XXIII on the methods of sovietisation. They included repressive legislation limiting the Church's possibility to exercise its rights in the countries of the entire Soviet bloc, putting pressure on the believers, mainly in the process of educating young people to be faithful to the ideals of socialist society, and using various forms of oppression [CEROV 11, 1962]. Listing the mentioned earlier strategies as applied by the communists might enable the better understanding of the forms in which the actions taken within the framework of the so-called sovietisation of the social or cultural life were manifested.

On January 29, 1964, "L'Osservatore Romano" published Professor F. Alessandrini's article on Polish bishops and their tough stance against the communist authorities of the PRL, the apologia for activity of the Polish Episcopal Conference, as well as the communists' strategy against the Church in Poland, together with the indication of specific elements of persecution. The author perceived the following elements of sovietisation conducted against the Church in Poland in the first half of the 1960s [CEROV 3, 1964]:

- attempts to discredit the Vatican and Western Christianity as submissive to progressive theology;

- financial support for the development of the PAX Association;

- carrying out propaganda activities among Catholics abroad, especially in France, to evoke the conviction of anachronistic organisation and isolation of the Polish Episcopal Conference;

- manipulation of propaganda and disinformation showing the Polish bishops' alleged rejection of some of the directives flowing from the Holy See;

- using the potential of "progressive Catholics", who were obedient to authorities, as successors of the patriot priests' movement, particularly popular in the 1950s.

The Catholic Church remained one of the main institutions, if not the most important, in the field of defence of the Polish society against sovietisation. In his sermon delivered in the Church of St Stanislaus in Rome on May 6, 1964, Primate Wyszynski said: "The Church in Poland took on the task of protecting human dignity, the Poles' dignity (...), and therefore we do not want, and we cannot part with the innate and supernatural Christian culture" [CEROV 8, 1964]. The implementation of the task was crucial since the Embassy of the Republic of Poland at the Vatican noted further occurrences of restricting civil liberties and undermining the foundations of the development of religious life and thus the development of the Catholic society in Poland by the PRL authorities. Among the specific manifestations of the interference of the communist state bodies, the following ones were mentioned [CEROV 1, 1964]:

- limitation of religious freedom and freedom of religious practices among children and youth, including the Polish People's Army;

- hindering access to church weddings and infant baptism in parishes;

- utilisation of schools to raise children and youth according to the spirit of atheistic theories through the impact of the reform abolishing teaching religion at public schools;

- imposing further financial burdens on the Catholic University of Lublin, as the main centre of higher education in the spirit of values characteristic of the Christian culture; 
- elimination of smaller seminaries and the submission of major seminaries to the power of state curators;

- mobilising seminarians for military service and thus limiting the possibility of proper development of the staff and organisation of the Church;

- liquidation of smaller seminaries and the submission of major seminaries to the power of state curators;

- mobilising seminary students for military service and thus reducing the possibility of proper personnel and organisational development of the Church;

- controlling of publishing the Catholic press resulting in a general reduction in the number of periodicals;

- getting the right by the authorities to approve the nomination of the parish priest based on the prerogative of the Office for Religious Affairs, with a simultaneous bureaucratic extension of the procedure itself;

- introduction of prohibitions and restrictions related to the construction of new sacred facilities;

- increasing the scope of actual actions of the Citizens' Militia and the Office for Religious Affairs in the sphere of controlling the functioning of the Church.

It should be assumed that the sovietisation of the Polish culture and society required the communist authorities to use differentiated instruments of influence not only on the Church but also on those circles that could maintain contact with any institution of Christian organisation guarding Christian values. Implications from the communists' involvement concerned schools and universities, especially the Catholic University of Lublin, social organisations as well as publishing and press centres. They referred to the indoctrination of soldiers in active military service, future clergy, or ordinary citizens striving to participate in the religious life of local communities.

The preserved archives show that from the very beginning of 1962, the Holy See attached great importance to celebrations of the millennium anniversary of Christian Baptism of Poland, which was on the one hand a factor that could potentially strengthen the social influence of the Church and on the other hand a problem from the point of view of the sovietisation strategy or policy implemented by the PRL authorities [CEROV 7, $1962]^{18}$. While preparing the plan for celebrating the millennium of the Baptism of Poland against the background of competitive propaganda activities of the PRL authorities that joined the planning of the millennium anniversary of the Polish State without regard for the religious nature of events, various topics were discussed [Rochatka 2007: 36-42] ${ }^{19}$. One of the most important issues was to schedule the pilgrimage of Pope Paul VI to Poland [CEROV 19, 1965], which finally did not take place due to the ban imposed by the communist authorities of the PRL [Bednarski 2016: 381]. Prohibitions and restrictions applied within the framework of the border protection policy were to constitute an additional way

18 The first communication testifying to it was the report prepared on March 8, 1962, summarising the audience of Primate Wyszynski with Pope John XXIII, when the question of the Polish Church was discussed in the perspective of preparations for the millennium of the Baptism of Poland and significant social problems in the communist PRL.

19 For more on the ideological dispute between the Church and the communist authorities of the People's Republic of Poland on occasion of the events of 1966. 
of protecting communist Poland from the inflow of foreign cultural content that could destabilise the model of the socialist society being shaped, which was subjected to the impact of sovietisation in the sphere of cultural security [Bielecki 2017: 177-178].

The Ambassador of the Polish Government in Exile at the Holy See, Kazimierz Papée, provided Interesting conclusions on the implications of the phenomenon of sovietisation for the planned celebrations of the millennium anniversary of the Baptism of Poland in the letter to the president of the Association of Polish Combatants "Italia", which was recorded by the Polish Embassy at the Vatican on March 30, 1965. It included the conviction about the autonomous character of the holiday regarding the communist authorities' activities that disregarded the religious nature of the celebration. Moreover, it expressed the need to make more considerable efforts to attract interest from the West in religious celebrations in Poland and highlight the benefits that Western European countries owed to Poland for its commitment to the fight against communism and Nazism after World War I ended. Numerous threats posed by the communists to weaken the significance of the Church celebrations of the millennium of Poland's Baptism, overcome Polish emigration, invigilate the Polish Government in Exile, as well as gain members of veteran organisations to cooperate with the PRL authorities were observed. One of the most important means of implementing the communist strategy was the activity of the Society of Fighters for Freedom and Democracy (ZBOWiD) subordinated to the Polish United Workers' Party $[\text { CEROV 6, 1965] }]^{20}$.

In the literature on the subject, one can find a thesis that the communist authorities of the PRL and the Church in Poland attempted to negotiate on the grounds of diplomatic efforts undertaken between Poland and the Holy See, the origin of which should be sought in 1965 [Kucharski 2013: 129]. However, archival sources preserved in the Polish Embassy at the Vatican made it possible to write about the attempt at reaching an agreement as a real postulate to be implemented in the mid-1960s. In the communication of the Embassy of May 31, 1965, the following conviction was expressed: "In fact, this 'dialogue' of communist regimes in Poland, Hungary and the Baltic States is a dialogue forced by rapes and persecution, because under these conditions the Church is looking for a modus vivendi for saving those remnants that the communist fury still has left. (...) It lacks the essential condition of every dialogue, which is freedom: one cannot be forced to participate in a dialogue. (...) One should talk about 'confrontation' between Catholicism and communists when it takes place on a cultural ground" [CEROV 31, 1965]. The obstacle to the productive dialogue between the communists in Poland and the Church was not so much Christians' fear of communist ideology but "the conviction that communism not only does not present any social, political and economic values but is a destroyer of human beings and human values" [Ibid.]. When interpreting the content of the Polish Embassy's communication to the Vatican, the environment related to the Apostolic Church did not anticipate the possibility of reaching an agreement between the Church and the communist countries,

20 The letter expresses the view that the Polish emigration is a "free expression of the essential needs of the nation" that undertakes actions to "restore Poland's true independence and rebuild the legitimate Polish state (...) by breaking the imposed knots of political, economic and cultural dependence on Moscow". The presented arguments contributed to the rhetoric of opposition to the directions of the sovietisation of the Polish culture and society imposed by the Polish People's Republic in the analysed years. 
including Poland, while sovietisation in the field of culture was assessed as a detrimental phenomenon to nations susceptible to the influence of the communist ideology.

While implementing the assumptions of the sovietisation strategy, the communist authorities sought to limit the Church's influence on the Polish society on occasion of the Polish-German reconciliation process due to the exchange of letters between Polish and German bishops. The communists recognised the initiative of Polish bishops as a manifestation of interference in the PRL foreign policy, a form of unauthorised representation of the entire Polish society's interests, and a detrimental element to the Polish raison detat. Communication with German bishops contributed to the intensification of the anti-church policy as an element of sovietisation in the country, while the Polish Embassy at the Vatican documented the action itself with considerable interest. In the communication of December 22, 1965, the undertaking of Polish bishops was recognised as "a creative initiative of historical significance for the entire world of Christian culture" [CEROV 29, 1965]. However, the communiqué of December 30,1965, noted a quick communists' counter-reaction, the aftermath of which were the exacerbated attacks on the Church and the attempts to discredit her actions in the eyes of citizens [CEROV 30, 1965].

In September 1967, in the document of the Polish Embassy at the Vatican, the reference was made to the absence of Polish bishops during the Synod initiated by Pope Paul VI. The Polish Episcopal Conference was not represented there as the communist authorities had prevented the journey. When opening the Synod, the Pope mentioned unrighteous conditions of existence that the regimes imposed on the functioning of the Church in some states. The Polish Embassy at the Vatican perceived it as a sign of criticism of the communist authorities of the People's Republic of Poland, with the simultaneous support and confirmation of the spiritual communion of the Synod with bishops of the Polish Episcopate. The Pope formulated arguments that the legitimate freedom was denied to the Church and that the institution suffered harassment from "legal and moral pressure and hostile anti-religious action" [CEROV 21, 1967], thereby the development of Christian culture and values in Catholic societies was jeopardised. It is worth noting that the authorities' refusal regarding the Polish bishops' travel to the Synod in Rome translated into a deterioration of the relations between the Church and the PRL authorities in view of attempts to start negotiations between the parties that were commented on in 1967 [Żaryn 2002: 35; CEROV 14, 1967 ${ }^{21}$. Obtaining support from the Pope - revealed during the opening speech at the Synod of Bishops in September 1967 in the arguments about the harmful influence of dictatorial and totalitarian regimes on the development of the Church - was

${ }^{21}$ In the literature, it is emphasised that the negotiations in question had little chance of success, mainly due to two key reasons. The first one was the Vatican's reluctance to accept the Polish communists' postulate regarding the official recognition of the Polish western and northern borders by the Holy See before the formal settlement of the matter under a separate agreement between Poland and the Federal Republic of Germany (it was not until December 1970). The second reason was related to the fact that the communist authorities suggested that Vatican diplomacy needed to deprive Primate Wyszynski of the position of chairman of the Polish Episcopal Conference, as well as break diplomatic relations with Kazimierz Papée, the then ambassador of the Polish Government in Exile at the Holy See. It should be stressed that the preserved archives also testify to disinformation activities undertaken by the communists to implement the postulates mentioned earlier. For example, an article published on May 25, 1965, in the Roman magazine "Il Passe" edited by a communist body publishing for the Italian intelligentsia informed about the possibility of liquidation of the Polish Embassy at the Vatican. The information required the immediate intervention of interested groups gathered around the Government of the Republic of Poland in Exile to rectify the false press release. 
to further strengthen the Polish clergy's expectations regarding the improvement of the institution's position and its impact on the Polish society [CEROV 22, 1967; CEROV 13, 1967; CEROV 18, 1965] $]^{22}$. As a result, the negotiating position of the PRL authorities in relations with the Church in Poland was weakened. What is more, the model for cultural and social sovietisation implemented since the early 1960s with the participation of the above forms of impact on the society was further discredited.

The Polish society's attachment to the Church in the second half of the 1960s is also evidenced by the mention of a future bishop in communist Poland, and later a cardinal, Agostino Casaroli, made in one of the communications of the Embassy of the Republic of Poland at the Vatican [Bilik 1993: 77; CEROV 5, 1967; CEROV 12, 1967] ${ }^{23}$. Following the stay of the future cardinal, difficulties arose in discussions between the PRL government and the Church in Poland, which prevented the creation of conditions of a lasting agreement and mutual recognition of the methods of state action, as well as the rights expected by the clergy. What is more, the Vatican diplomat noted: "My impressions of the latter journey have fully confirmed the positive judgment about the extraordinary vitality of the Church in Poland, the attachment of a clear majority of the nation to the Catholic religion and the devotion and worship of the Holy Father. I witnessed this on several occasions" $[C E R O V 8,1967]$. It can be presumed that the actions of the communist state that fitted into the direction of the sovietisation of the culture and social life in Poland - especially those focused on eliminating the influence of the Church and religion from the society did not bring the results expected by politicians.

In 1968, the communication of the Embassy of the Republic of Poland at the Vatican included an interesting description of the accidents that took place in March at the University of Warsaw, namely protests of students, inspired by part of the academic staff.

22 The support was not incidental but it also appeared on other occasions, which can be exemplified by a fragment of the papal homily recorded by the Polish Embassy at the Vatican on May 19, 1967, when the head of the Church referred to the problems of restricting religious freedom and negating the existence of God in the countries of the Soviet bloc. In turn, during a service in the catacombs of St Domitilla of September 12, 1965, Pope Paul VI condemned the persecution of Christians in the communist countries. He denied the Vatican's ability to deal with atheist governments, in which the resistance of the clergy and believers is overcome with "all technical means of modern civilisation", thereby depriving citizens of the holiest right to truth and responsible freedom in the required field of conscience and faith. The goal is to suppress the voice of the Church and exterminate religion.

23 Interestingly, Casaroli was, in fact, the primary person responsible for leading the Vatican's policy and diplomacy concerning the countries of the Soviet bloc. It was a consequence of the establishment of the Council for Public Affairs of the Church by Pope Paul VI in August 1967, as the specialised body for conducting the foreign policy of the Vatican, headed by Casaroli. Several Casaroli's arrivals at Warsaw were to serve mainly the goal of preparing Polish bishops from the Polish Episcopate to talk with the government. The visits were planned to contribute to elaborating the foundations and program for possible negotiations of the highest hierarchs of the Polish Catholic Church with the communist regime, although archival sources suggest that Catholic sources doubted the implementation of such a postulate of Vatican diplomacy. The editor-in-chief of "L'Osservatore Romano", Professor F. Alessandrini, expressed concerns about the agreement and in the article titled "Discrepancies" he underlined the fundamental and irreconcilable differences between the ideology of communism and the assumptions of Catholicism. They mainly related to a different understanding of human rights and human freedom. Communism made their understanding dependent on the economic system adopted and the need to end the class struggle by allowing the force to justify the ultimate objective, while for Catholic social teaching man is free by nature and divine law and has the right to control economic reality and its institutions for the protection of freedom. The above message should be treated as additional support for the opposition of Catholic societies in the entire Soviet bloc against the model of sovietisation of culture and social development imposed upon them. 
The student protest turned into a mass manifestation and ended with the clash with the security services, thus embedding itself into the broader context of the events of March 1968. It was a direct response of young people and other social groups to the direction of sovietisation of Polish culture and social life being implemented, focused on the opposition and requesting authorities of the People's Republic of Poland to respect fundamental civil rights. The report on events in the official Vatican daily highlighted specific allegations of the intelligentsia circles regarding the actions of the authorities. They included, among others, violation of elementary human rights, the use of extensive censorship preventing creative freedom and the freedom to proclaim beliefs, police authorities' interference in academic life, creating with the support of the authorities of the so-called "workers' teams" infiltrating students and professors' circles and supporting the anti-Semitic attitudes at the University of Warsaw by the regime. All these make the reader aware of the concrete forms of the PRL authorities' actions inscribed in the direction of sovietisation of the culture and the Polish society in the analysed years. According to the Polish Embassy at the Vatican, it was necessary to make the Vatican and Italian press more aware of the essence and character of mass student occurrences in Poland and the protests initiated by other socio-professional groups in March 1968. The abovementioned communication expressed the following conviction: "In Poland, violation of fundamental human rights comes into play, and the communist regime enforced from outside suppresses the freedom of man and nation at every step. The same causes as formerly in Poland and Hungary also come about in Romania and Czechoslovakia (...). In Poland, a great game between society and the regime began. (...) The regime is undoubtedly in trouble" [CEROV 7, 1968]. It should be assumed that 1968 was a breakthrough in the summary of the period of sovietisation in the 1960s. The escalation of social anger and the massive protests of the Polish society of March 1968 were clear examples of opposition towards sovietisation and the communists' attempts to eradicate the values, traditions and beliefs that the Polish nation had adhered to for many centuries, with a significant contribution of Christian values [Eisler 1991: 323]24.

\section{Sumary and Conclusions}

Sovietisation of Polish culture and society during these two periods characterised the differences in the PRL authorities' politics, which were caused by the efficiency of informational activities of the Catholic Church and the influence of the Catholic Church on international public opinion. The analysed period shows that the Catholic Church was instrumental in the process of sovietisation od Polish culture and society. At the same time, the Catholic Church turned out to be the only institution able to change the PRL authorities' conduct. The presented arguments allow for formulating the following general conclusions:

1. The documents preserved by the Polish Embassy at the Vatican attest to the Church's particularly active role in preserving the Polish cultural values and foundations for the

24 Nonetheless, as Jerzy Eisler pointed out, the grounds for the outbreak of mass protests should be sought not only in the social and cultural sphere, but also on economic grounds in connection with the growing economic difficulties of the state and the deteriorating financial situation of many socio-professional groups. 
development of social life, as well as opposition towards the imposed sovietisation of social security and cultural security of the Polish People's Republic in 1956-1968.

2. The sovietisation concerned various manifestations of the development of cultural security and social security in the PRL in the years 1962-1968. The strategy applied by the communists consisted in the formulation of prohibitions, restrictions and restrictive subordination of all social environments. It applied numerous forms of persecution of the Catholic Church as a particularly representative institution of social life and an organisation protecting the values of Christian culture.

3. Structuring dialogue between the Catholic Church and the communist state on the example of the Polish People's Republic of the 1950 and 1960s, based on partnership and peaceful co-existence, remained a postulate impossible to implement under specific political and social conditions.

The presented archival material corresponds with the thesis of the paper that the years 1956-1968 were characterised by the continuity of the Catholic Church's mission implementation in the service of protecting the Polish culture and society from the directions of sovietisation imposed by the communist authorities in comparison to 1956-1961. Facing the fact that the authorities of the Polish People's Republic took advantage of various forms of persecution of the Church, but also of all circles identifying with the values of Christian culture, a decisive voice of opposition, supported by the Holy See, was necessary. The Church opposed, in the whole examined perspective, any actions aimed at eradicating Christian values from the Polish culture and social relations in Poland. Given the archival materials collected by the Polish Embassy at the Vatican, the Catholic opposition to the sovietisation of the Polish culture and social life in the years 1962-1968 should be shown as very effective.

\section{Bibliography}

Communication of the Embassy of the Republic of Poland at the Vatican No. 22 of April 18, 1956 [CEROV 22, 1956], entitled The economic communist system in the opinion of the Pope, Józef Piłsudski Institute of America, Polish Embassy at the Vatican, folder: 701/12/3 (Communications: "Information Service of the Embassy of the Republic of Poland at the Vatican" and "Informazioni Della Polonia").

Communication of the Embassy of the Republic of Poland at the Vatican No. 23 of May 5, 1956 [CEROV 23, 1956], Józef Piłsudski Institute of America, Polish Embassy at the Vatican, folder: 701/12/3 (Communications: "Information Service of the Embassy of the Republic of Poland at the Vatican" and "Informazioni Della Polonia”).

Communication of the Embassy of the Republic of Poland at the Vatican No. 32 of June 25, 1956 [CEROV 32, 1956], Józef Piłsudski Institute of America, Polish Embassy at the Vatican, folder: 701/12/3 (Communications: "Information Service of the Embassy of the Republic of Poland at the Vatican" and "Informazioni Della Polonia").

Communication of the Embassy of the Republic of Poland at the Vatican No. 35 of March 7, 1956 [CEROV 35, 1956], Józef Piłsudski Institute of America, Polish Embassy at the Vatican, folder: 701/12/3 (Communications: "Information Service of the Embassy of the Republic of Poland at the Vatican" and "Informazioni Della Polonia").

Communication of the Embassy of the Republic of Poland at the Vatican No. 39 of July 16, 1956 [CEROV 39, 1956], Józef Piłsudski Institute of America, Polish Embassy at the Vatican, folder: 701/12/3 (Communications: "Information Service of the Embassy of the Republic of Poland at the Vatican" and "Informazioni Della Polonia”). 
Communication of the Embassy of the Republic of Poland at the Vatican No. 45 of September 24, 1956 [CEROV 45, 1956], Józef Piłsudski Institute of America, Polish Embassy at the Vatican, folder: 701/12/3 (Communications: "Information Service of the Embassy of the Republic of Poland at the Vatican" and "Informazioni Della Polonia").

Communication of the Embassy of the Republic of Poland at the Vatican No. 51 of October 29, 1956 [CEROV 51, 1956], Józef Piłsudski Institute of America, Polish Embassy at the Vatican, folder: 701/12/3 (Communications: "Information Service of the Embassy of the Republic of Poland at the Vatican" and "Informazioni Della Polonia").

Communication of the Embassy of the Republic of Poland at the Vatican No. 52 of October 30, 1956 [CEROV 52, 1956], Józef Piłsudski Institute of America, Polish Embassy at the Vatican, folder: 701/12/3 (Communications: "Information Service of the Embassy of the Republic of Poland at the Vatican" and "Informazioni Della Polonia").

Communication of the Embassy of the Republic of Poland at the Vatican No. 5 of February 26, 1958 [CEROV 5, 1958], Józef Piłsudski Institute of America, Polish Embassy at the Vatican, folder: 701/12/5 (Communications: "Information Service of the Embassy of the Republic of Poland at the Vatican" and "Informazioni Della Polonia").

Communication of the Embassy of the Republic of Poland at the Vatican No. 1 of January 12, 1960 [CEROV 1, 1960], Józef Piłsudski Institute of America, Polish Embassy at the Vatican, folder: 701/12/7 (Communications: "Information Service of the Embassy of the Republic of Poland at the Vatican" and "Informazioni Della Polonia").

Communication of the Embassy of the Republic of Poland at the Vatican No. 6 of February 27, 1960 [CEROV 6, 1960], Józef Piłsudski Institute of America, Polish Embassy at the Vatican, folder: 701/12/7 (Communications: "Information Service of the Embassy of the Republic of Poland at the Vatican" and "Informazioni Della Polonia").

Communication of the Embassy of the Republic of Poland at the Vatican No. 7 of March 7, 1960 [CEROV 7, 1960], Józef Piłsudski Institute of America, Polish Embassy at the Vatican, folder: 701/12/7 (Communications: "Information Service of the Embassy of the Republic of Poland at the Vatican" and "Informazioni Della Polonia").

Communication of the Embassy of the Republic of Poland at the Vatican No. 4 of February 3, 1961 [CEROV 4, 1961], Józef Piłsudski Institute of America, Polish Embassy at the Vatican, folder: 701/12/8 (Communications: "Information Service of the Embassy of the Republic of Poland at the Vatican" and "Informazioni Della Polonia").

Communication of the Embassy of the Republic of Poland at the Vatican No. 6 of February 18, 1961 [CEROV 6, 1961], Józef Piłsudski Institute of America, Polish Embassy at the Vatican, folder: 701/12/8 (Communications: "Information Service of the Embassy of the Republic of Poland at the Vatican" and "Informazioni Della Polonia").

Communication of the Embassy of the Republic of Poland at the Vatican No. 7 of April 13, 1961 [CEROV 7, 1961], Józef Piłsudski Institute of America, Polish Embassy at the Vatican, folder: 701/12/8 (Communications: "Information Service of the Embassy of the Republic of Poland at the Vatican" and "Informazioni Della Polonia").

Communication of the Embassy of the Republic of Poland at the Vatican No. 9 of March 27, 1961 [CEROV 9, 1961], Józef Piłsudski Institute of America, Polish Embassy at the Vatican, folder: 701/12/8 (Communications: "Information Service of the Embassy of the Republic of Poland at the Vatican" and "Informazioni Della Polonia").

Communication of the Embassy of the Republic of Poland at the Vatican No. 10 of March 24, 1961 [CEROV 10, 1961], Józef Piłsudski Institute of America, Polish Embassy at the Vatican, folder: 701/12/8 (Communications: "Information Service of the Embassy of the Republic of Poland at the Vatican" and "Informazioni Della Polonia").

Communication of the Embassy of the Republic of Poland at the Vatican No. 28 of September 27, 1961 [CEROV 28, 1961], Józef Piłsudski Institute of America, Polish Embassy at the Vatican, folder: 701/12/8 (Communications: "Information Service of the Embassy of the Republic of Poland at the Vatican" and "Informazioni Della Polonia").

Communication of the Embassy of the Republic of Poland at the Vatican No. 1 of January 3, 1962 [CEROV 1, 1962], Józef Piłsudski Institute of America, the Polish Embassy at the Vatican, folder: 701/12/9 
(Communications: "Information Service of the Embassy of the Republic of Poland at the Vatican" and "Informazioni Della Polonia").

Communication of the Embassy of the Republic of Poland at the Vatican No. 4 of February 3-4, 1962 [CEROV 4, 1962], Józef Piłsudski Institute of America, the Polish Embassy at the Vatican, folder: 701/12/9 (Communications: "Information Service of the Embassy of the Republic of Poland at the Vatican" and "Informazioni Della Polonia").

Communication of the Embassy of the Republic of Poland at the Vatican No. 7 of March 8, 1962 [CEROV 7, 1962], Józef Piłsudski Institute of America, the Polish Embassy at the Vatican, folder: 701/12/9 (Communications: "Information Service of the Embassy of the Republic of Poland at the Vatican" and "Informazioni Della Polonia”).

Communication of the Embassy of the Republic of Poland at the Vatican No. 10 of March 21, 1962 [CEROV 10, 1962], Józef Piłsudski Institute of America, the Polish Embassy at the Vatican, folder: 701/12/9 (Communications: "Information Service of the Embassy of the Republic of Poland at the Vatican" and "Informazioni Della Polonia").

Communication of the Embassy of the Republic of Poland at the Vatican No. 11 of March 26, 1962 [CEROV 11, 1962], Józef Piłsudski Institute of America, the Polish Embassy at the Vatican, folder: 701/12/9 (Communications: "Information Service of the Embassy of the Republic of Poland at the Vatican" and "Informazioni Della Polonia").

Communication of the Embassy of the Republic of Poland at the Vatican No. 3 of January 20, 1964. [CEROV 3, 1964], Piłsudski Institute of America, the Polish Embassy at the Vatican, folder: 701/12/11 (Communications: "Information Service of the Embassy of the Republic of Poland at the Vatican" and "Informazioni Della Polonia").

Communication of the Embassy of the Republic of Poland at the Vatican No. 13 of May 8, 1964 [CEROV 8, 1964], Józef Piłsudski Institute of America, the Polish Embassy at the Vatican, folder: 701/12/11 (Communications: "Information Service of the Embassy of the Republic of Poland at the Vatican" and "Informazioni Della Polonia".

Communication of the Embassy of the Republic of Poland at the Vatican No. 13 of May 8, 1964, Józef Piłsudski Institute of America, the Polish Embassy at the Vatican, folder: 701/12/11 (Communications: "Information Service of the Embassy of the Republic of Poland at the Vatican" and "Informazioni Della Polonia").

Communication of the Embassy of the Republic of Poland at the Vatican on June 1, 1964 [CEROV 1, 1964], entitled Information from Poland. Religious situation in Poland, Józef Piłsudski Institute of America, Polish Embassy at the Vatican, folder: 701/12/11 (Communications: "Information Service of the Embassy of the Republic of Poland at the Vatican" and "Informazioni Della Polonia").

Communication of the Embassy of the Republic of Poland at the Vatican No. 6 of March 30, 1965 [CEROV 6, 1965], Józef Piłsudski Institute of America, the Polish Embassy at the Vatican, folder: 701/12/12 (Communications: "Information Service of the Embassy of the Republic of Poland at the Vatican" and "Informazioni Della Polonia").

Communication of the Embassy of the Republic of Poland at the Vatican No. 31 of May 31, 1965 [CEROV 31, 1965], Józef Piłsudski Institute of America, the Polish Embassy at the Vatican, folder: 701/12/12 (Communications: "Information Service of the Embassy of the Republic of Poland at the Vatican" and "Informazioni Della Polonia").

Communication of the Embassy of the Republic of Poland at the Vatican No. 18 of September 14, 1965 [CEROV 18, 1965], Józef Piłsudski Institute of America, the Polish Embassy at the Vatican, folder: 701/12/12 (Communications: "Information Service of the Embassy of the Republic of Poland at the Vatican" and "Informazioni Della Polonia").

Communication of the Embassy of the Republic of Poland at the Vatican No. 19 of September 16, 1965 [CEROV 19, 1965], Józef Piłsudski Institute of America, the Polish Embassy at the Vatican, folder: 701/12/12 (Communications: "Information Service of the Embassy of the Republic of Poland at the Vatican" and "Informazioni Della Polonia").

Communication of the Embassy of the Republic of Poland at the Vatican No. 29 of December 13, 1965 [CEROV 29, 1965], Józef Piłsudski Institute of America, the Polish Embassy at the Vatican, folder: 701/12/12 (Communications: "Information Service of the Embassy of the Republic of Poland at the Vatican" and "Informazioni Della Polonia"). 
Communication of the Embassy of the Republic of Poland at the Vatican No. 30 of December 22, 1965 [CEROV 30, 1965], Józef Piłsudski Institute of America, the Polish Embassy at the Vatican, folder: 701/12/12 (Communications: "Information Service of the Embassy of the Republic of Poland at the Vatican" and "Informazioni Della Polonia").

Communication of the Embassy of the Republic of Poland at the Vatican No. 5 of February 16, 1967 [CEROV 5, 1967], Józef Piłsudski Institute of America, the Polish Embassy at the Vatican, folder: 701/12/14 (Communications: "Information Service of the Embassy of the Republic of Poland at the Vatican" and "Informazioni Della Polonia").

Communication of the Embassy of the Republic of Poland at the Vatican No. 8 of March 29, 1967 [CEROV 8, 1967], Józef Piłsudski Institute of America, the Polish Embassy at the Vatican, folder: 701/12/14 (Communications: "Information Service of the Embassy of the Republic of Poland at the Vatican" and "Informazioni Della Polonia").

Communication of the Embassy of the Republic of Poland at the Vatican No. 12 of May 5, 1967 [CEROV 12, 1967], Józef Piłsudski Institute of America, the Polish Embassy at the Vatican, folder: 701/12/14 (Communications: "Information Service of the Embassy of the Republic of Poland at the Vatican" and "Informazioni Della Polonia").

Communication of the Embassy of the Republic of Poland at the Vatican No. 13 of May 19, 1967 [CEROV 13, 1967], Józef Piłsudski Institute of America, the Polish Embassy at the Vatican, folder: 701/12/14 (Communications: "Information Service of the Embassy of the Republic of Poland at the Vatican" and "Informazioni Della Polonia").

Communication of the Embassy of the Republic of Poland at the Vatican No. 14 of June 16, 1967 [CEROV 14, 1967], Józef Piłsudski Institute of America, the Polish Embassy at the Vatican, folder: 701/12/12 (Communications: "Information Service of the Embassy of the Republic of Poland at the Vatican" and "Informazioni Della Polonia").

Communication of the Embassy of the Republic of Poland at the Vatican No. 22 of October 11, 1967 [CEROV 22, 1967], Józef Piłsudski Institute of America, the Polish Embassy at the Vatican, folder: 701/12/14 (Communications: "Information Service of the Embassy of the Republic of Poland at the Vatican" and "Informazioni Della Polonia").

Communication of the Embassy of the Republic of Poland at the Vatican No. 21 of September 29, 1967 [CEROV 21, 1967], Józef Piłsudski Institute of America, the Polish Embassy at the Vatican, folder: 701/12/14 (Communications: "Information Service of the Embassy of the Republic of Poland at the Vatican" and "Informazioni Della Polonia").

Communication of the Embassy of the Republic of Poland at the Vatican No. 7 of March 14, 1968 [CEROV 7, 1968], Józef Piłsudski Institute of America, the Polish Embassy at the Vatican, folder: 701/12/15 (Communications: "Information Service of the Embassy of the Republic of Poland at the Vatican" and "Informazioni Della Polonia").

\section{Books and articles}

Act of 15 July 1961 on the development of the education and upbringing system [DEUS]. Journal of Laws of 1961, No. 32, item 160 .

Act of July 15, 1961, on the development of the education and upbringing system [DEUS, 1961]. Journal of Laws of 1961, No. 32, item 160.

Bednarski, Krzysztof [2016]. Watykan i Paweł VI wobec milenium chrztu Polski (w relacji ambasadora Kazimierza Papée). Śląskie Studia Historyczno-Teologiczne 49 (2): 371-389.

Bielicki, Paweł [2017]. “Źelazna kurtyna” jako aspekt sowietyzacji Europy Wschodniej w latach 1949-1953. Studia z Dziejów Rosji i Europy Środkowo-Wschodniej 52 (1): 175-200.

Bilik, Anrzej [1993]. Politycy. Czterdziestu siedmiu wielkich. Warsaw: Polska Oficyna Wydawnicza BGW. Bodziany, Marek [2019]. Wewnętrzne uwarunkowania bezpieczeństwa kulturowego Polski. Wrocław: AWL. Chmielowiec, Piotr - Lasota, Marek - Szarek, Jarosław - Terlecki, Ryszard [2003]. Kościół w godzinie próby 1945-1989. Nieznane dokumenty i świadectwa. Krakow: Dom Wydawniczy "Rafael".

Decree of December 31, 1956, on organising and filling clerical positions [OFCP, 1957]. Journal of Laws of 1957, No. 1, item 6. 
Decree of February 9, 1953, on filling clerical positions. Journal of Laws of 1953, No. 10, item 32.

Dominiczak, Henryk [2000]. Organy bezpieczeństwa PRL w walce z Kościołem katolickim. W świetle dokumentów MSW. Warsaw: Bellona.

Dudek, Antoni [1995]. Państwo i Kościół w Polsce 1945-1979. Krakow: PiT.

Dudek, Antoni - Gryz, Ryszard [2006]. Komuniści i Kościół w Polsce (1945-1989). Krakow: ZNAK.

Dzwonkowski, Roman [2012]. Laudacja na część księdza arcybiskupa Szczepana Wesołego, 9 października 2007 roku. In. Nir, Roman - Szczerbiński, Marek - Wasilewski, Krzysztof (eds.). W nieustającej trosce o polska diasporę. Studia historyczne i politologiczne. Gorzów Wielkopolski: Stowarzyszenie Naukowe "Polska w świecie", p. 56.

Eisler, Jerzy [1991]. Marzec 1968. Geneza, przebieg, konsekwencje. Warsaw: PWN.

Eisler, Jerzy [2004]. Stosunki Kościół-państwo w powojennej Polsce w najnowszych publikacjach. Pamięć i Sprawiedliwość, nr. 3: 1.

Gałaszewska-Chilczuk, Dorota [2006]. Polityka państwa wobec Katolickiego Uniwersytetu Lubelskiego w latach 1944-1968. Pamięć i Sprawiedliwość, nr. 10.

Grajewski, Andrzej [2013]. Normalizacja administracji kościelnej na Ziemiach Zachodnich $w$ kontekście watykańskiej polityki wschodniej. In. Kucharski, Władysław (ed.). Droga do stabilizacji administracji kościelnej na Ziemiach Zachodnich i Pólnocnych po II wojnie światowej. Wrocław: Ośrodek "Pamięć i Przyszłość".

Grzybowski, Romuald [2012]. Socjalizacja w cieniu konfliktu Sytuacja wychowawcza dzieci $i$ młodzieży w Polsce w latach rządów Władysława Gomułki (1956-1970). Przegląd Pedagogiczny, nr. 1, 143-158.

Habielski, Rafał [2009]. Przeszłość i pamięć historyczna w życiu kulturalnym PRL. Kilka uwag wstępnych. In. Skibiński, Paweł - Wiścicki, Tomasz (eds.). Polityka czy propaganda: PRL wobec historii. Warsaw: Muzeum Historii Polski, pp. 87-115.

Impressions from the Polish Primate's stay in Rome /8. 5. - 8. 6. 1957/ [IPPR, 8. 5. 1957]. Józef Piłsudski Institute of America, Embassy of the Republic of Poland at the Vatican, folder: 701/12/1 (Communications: "Information Service of the Embassy of the Republic of Poland at the Vatican" and "Informazioni Della Polonia").

Kolasa, Krzysztof [2010]. Działania władz terenowych oraz aparatu bezpieczeństwa wobec placówek oświatowo-wychowawczych ss. salezjanek w Łodzi i ich likwidacja. Pamięć i Sprawiedliwość 1 (15): 383-410.

Krajczyński, Jan [2017]. Wybrane problemy Kościoła katolickiego w PRL w zakresie realizacji własnej misji. Acta UniversitatisLodziensis. Folia Iuridica 80: 55-77.

Krawczyk, Michał [2017]. Zarys polityki podatkowej władz PRL wobec Kościoła i duchowieństwa - studium historyczno-prawne. Zeszyty Naukowe Uniwersytetu Przyrodniczo-Humanistycznego w Siedlcach. Administracja i Zarzadzanie (112): 141-157.

Kucharski, Wojciech [2013]. Stabilizacja polskiego Kościoła na Ziemiach Zachodnich i Północnych w świetle raportów polskich dyplomatów w Rzymie z lat 1945-1972. In. Kucharski, Wojciech (ed.). Droga do stabilizacji administracji kościelnej na Ziemiach Zachodnich i Północnych po II wojnie światowej. Wrocław: Ośrodek Pamięć i Przyszłość, pp. 121-136.

Landmann, Tomasz [2017a]. Wpływ sowietyzacji polskiej kultury na poczucie bezpieczeństwa obywateli w latach 1945-1961 - na przykładzie Kościoła katolickiego. In. Grabińska, Teresa - Kuźniar, Zbigniew (eds.). Bezpieczeństwo personalne a bezpieczeństwo strukturalne. Kulturowe uwarunkowania bezpieczeństwa personalnego i społecznego. Vol. 5. Wrocław: WSOWL, pp. 344-360.

Landmann, Tomasz [2017b]. Wpływ sowietyzacji polskiej kultury na poczucie bezpieczeństwa obywateli w latach 1945-1961 - na przykładzie wybranych grup społecznych. In. Gitling, Maciej - Wojaczek, Ireneusz (eds.). Zagrożenia ładu społecznego oraz bezpieczeństwa narodowego. Wybrane aspekty. Przemyśl, pp. 143-158.

Marecki, Józef - Musiał, Filip [2007]. Wprowadzenie. In. Marecki, Józef - Musiał, Filip (eds.). Nigdy przeciw Bogu. Komunistyczna bezpieka wobec biskupów polskich. Warsaw - Kraków: WAM.

Mezglewski, Artur [2000]. Nauczanie religii w Polsce Ludowej. Studia z Prawa Wyznaniowego, nr. 1.

Mezglewski, Artur [2002]. Proces likwidacji niższych seminariów duchownych w latach 1959-1963. Studia z Prawa Wyznaniowego 4: 31-57.

Miernik, Grzegorz [2003]. Polacy wobec PRL. Strategie przystosowawcze. Kielce: Kieleckie Towarzystwo Naukowe. 
Pawlina, Krzysztof [2002]. Powołania do kapłaństwa w Polsce po II wojnie światowej. Przeglad Powszechny, nr. 10.

Regulation of the Minister of Finance of February 20, 1962 on keeping of accounts by church legal persons and religious orders and congregations [KCR]. Journal of Laws 1962, No. 18, item 77.

Rochatka, Tomasz [2007]. Walka propagandowa dotycząca orędzia biskupów i Milenium w prasie polskiej. In. Białecki, Konrad - Jankowiak, Stanisław - Miłosz, Jan (eds.). Milenium kontra Tysiaclecie - 1966. Poznań: IPN, pp. 36-42.

Stanisz, Piotr [2000]. Ideologiczne podstawy polityki wyznaniowej w PRL. Resovia Sacra. Studia Teologiczno-Filozoficzne Diecezji Rzeszowskiej, nr. 7.

Szafrański, Tadeusz [2005]. Historia Kościoła w Polsce. Mały słownik. Warsaw: Verbinum.

Wronikowska, Dominika [2016]. Stan badań. In. D. Wronikowska (ed.). Ambasada RP przy Stolicy Apostolskiej w latach 1919-1976. Materiały do studiów nad historią. Rzym: Grafica Metelliana.

Zabłocki, Janusz [1999]. Chrześcijańska demokracja w kraju i na emigracji 1947-1970. Lublin: Ośrodek studiów polonijnych i społecznych PZKS.

Żaryn, Jan [1998]. Stolica Apostolska wobec Polski i Polaków w latach 1944-1958 w świetle materiałów Ambasady RP przy Watykanie. Warsaw: Neriton - Instytut Historii PAN.

Żaryn, Jan [2002]. Dyplomacja PRL wobec Watykanu, czyli o instrumentalnym traktowaniu partnera. Biuletyn IPN 7: 32-38.

Żaryn, Jan [2003]. Dzieje Kościoła Katolickiego w Polsce (1944-1989). Dzieje Najnowsze. Warsaw: Neriton, Instytut Historii Pan.

Żaryn, Jan [2004]. Aparat bezpieczeństwa wobec Kościoła katolickiego w Polsce (1944-1980). In. Grzeskowiak, Alicja (ed.). Represje wobec osób duchownych i konsekrowanych w PRL w latach 1944-1989. Lublin: KUL.

Żaryn, Jan [2005]. Kościół katolicki w PRL: wybrane zagadnienia, hipotezy, prowokacje. Pamięć i Sprawiedliwość, nr. 4: 1.

Żaryn, Jan [2010]. Państwo-Kościół katolicki w Polsce 1956-1989 (wybrane zagadnienia), in: Polski wiek $X X$, vol. 4. Warsaw: Bellona.

Ziętara, Piotr [2001]. Emigracja wobec Października. Postawy polskich środowisk emigracyjnych wobec liberalizacji $w$ PRL w latach 1955-1957. Warsaw: LTW.

Marek Bodziany is doctor of sociology, post-doctoral degree of security sciences, Deputy Dean of Security Studies in General Kościuszko Military University of Land Forces in Wroclaw Faculty of Security Sciences, Editor-in-Chief of the MALF Publishing House. Scientific interests: multiculturalism, migration, social conflicts and crises, cultural security, methodology.

Tomasz Landmann is a doctor of humanities in the discipline of history. General Kościuszko Military University of Land Forces in Wroclaw. Scientific interests: contemporary history, national security, cultural security, protection of cultural goods. 